\title{
İstatistik Kaygı Ölçeğinin (SAS) Psikometrik Özelliklerinin İncelenmesi*
}

\author{
Hakan BEKTAŞ $S^{* *}$, Sema ULUTÜRK AKMAN ${ }^{* * *}$, Ege YEŞiLALTAY***
}

Öz

$\mathrm{Bu}$ çalışmanın amacı, Vigil-Colet ve diğerleri (2008) tarafından geliştirilmiş istatistik kaygı ölçeğinin Türkçe versiyonunun psikometrik özelliklerinin incelenmesidir. $\mathrm{Bu}$ amaç doğrultusunda sosyal bilimler alanındaki bir lisans diploma programında istatistik dersi almış ve sınavına girmiş öğrencilerden anket yoluyla veri toplanmıştır. Bu kapsamda çalışmaya gönüllülük esasına göre 350 öğrenci katılmış ve toplanan veri kümesinden hareketle; açıklayıcı faktör analizi, korelasyon ve güvenilirlik analizleri uygulanmıştır. Uygulanan açıklayıcı faktör analizi neticesinde keşfedilen faktör yapısının ölçeğin orijinal faktör yapısıyla uyumlu olduğu saptanmıștır. Dolayısıyla literatürdeki haliyle istatistik kaygısının alt faktörleri; sınav kaygısı, yardım isteme kaygısı ve yorumlama kaygısı olarak adlandırılmıştır. Söz konusu bulgularla, çalışmada toplanan veri kümesinin geçerlilik özelliğine sahip olduğu sonucuna varılmıştır. Çalışma kapsamında güvenilirlik analizi için içsel tutarlılığı göstermek üzere Cronbach alfa katsayısı hesaplanmıştır. Bu bağlamda, her bir faktör için hesaplanan Cronbach alfa katsayısı ise güvenilirlik özelliği açısından bulgu oluşturmuştur. Dolayısıyla istatistik kaygı ölçeğinin Türkçe versiyonunun geçerlilik ve güvenilirlik özelliklerine sahip olduğu sonucuna varılmıştır.

Anahtar Kelimeler: Geçerlilik, Güvenilirlik, İstatistik Kaygısı, İstatistik Kaygı Ölçeği, Faktör Analizi

\section{An Examination of the Psychometric Properties of the Statistical Anxiety Scale}

(SAS)

\section{Abstract}

This study aims to investigate the psychometric properties of the Turkish version of the Statistical Anxiety Scale developed by Vigil-Colet et al. (2008). 350 social science

\section{Özgün Araștırma Makalesi (Original Research Article) \\ Geliş/Received: 02.10 .2019 \\ Kabul/Accepted: 31.08 .2020 \\ DOI: https://dx.doi.org/10.17336/igusbd.627197}

* Bu çalışmanın özet metni, 12-13 Ekim 2017 tarihlerinde Konya'da gerçekleştirilen I. Uluslararası Sosyal ve Ekonomik Araştırmalar Öğrenci Kongresi (ISERSC) bildiri kitabında “Üniversite Öğrencilerinde İstatistik Kaygısı" başlığıyla yayımlanmıștır.

${ }^{* *}$ Dr. Öğr. Üyesi, İstanbul Üniversitesi, İktisat Fakültesi, Ekonometri Bölümü, İstanbul, Türkiye, E-posta: hbektas@istanbul.edu.tr ORCID https://orcid.org/0000-0002-7856-2674

*** Doç. Dr., İstanbul Üniversitesi, İktisat Fakültesi, Ekonometri Bölümü, İstanbul, Türkiye, E-posta: akmans@istanbul.edu.tr ORCID https://orcid.org/0000-0002-4075-8313

${ }^{* * * *}$ Yüksek Lisans Öğrencisi, İstanbul Üniversitesi, Sosyal Bilimler Enstitüsü, Ekonometri Anabilim Dalı, İstatistik Programı, İstanbul, Türkiye, E-posta: egeyesilaltay@gmail.com ORCID https://orcid.org/0000-0002-3011-3204 
undergraduate students who enrolled in a statistics course and took the course exam participated in the study voluntarily. Data were collected via survey and explanatory factor analysis, correlation, and also reliability analysis was conducted. The findings of explanatory factor analysis are consistent with the original factor structure of the scale. Therefore, the sub-factors of Statistical Anxiety are named as it was in the literature; examination anxiety, asking for help anxiety, and interpretation anxiety. The finding suggests that the data set collected in the study indicates validity. Cronbach's alpha coefficient was also calculated for internal consistency for reliability analysis. Cronbach's alpha coefficients calculated for each factor show that the scale is reliable. Therefore, it is concluded that the Turkish version of the statistical anxiety scale ensures validity and reliability. Analysis

Keywords: Validity, Reliability, Statistics Anxiety, Statistical Anxiety Scale, Factor

\section{Giriş}

İnsanoğlu karşı karşıya kaldığı olgulara bağlı olarak çeşitli duygu durumları geliştirir. Sözgelimi, güzel bir haber ya da bir hediye aldığında sevinç, sıra beklerken sırasının bir başkası tarafından gasp edilmesinde öfke, karşıdan karşıya geçerken hızla gelmekte olan bir araçla korku, sevdiği bir yakınını kaybettiğinde üzüntü duyar. Bu örnekleri arttırmak mümkündür. Dikkat edilecek olursa, tüm duygu durumları dışarıdan gelen bir uyarı üzerine gelişmektedir.

Korku ve kaygı günlük konuşma dilinde eş anlamlı kullanılmakla beraber gerçekte farklı anlamları olan iki sözcüktür. Korku ve kaygı, her ikisi de, dışsal bir uyarana karşı insanın geliştirdiği bir duygu durumudur. Dolayısıyla, uyaran diş dünyadan gelmekle beraber kişinin onlara yüklediği anlam aradaki farkı oluşturmaktadır.

Kişi, maruz kaldığı olaya fiziksel bir risk ya da tehdit anlamı yüklüyorsa gelişen duygunun adı korku; kişiliğine yönelik bir risk ya da tehdit anlamı yüklüyorsa gelişen duygunun adı kaygı (anksiyete) olmaktadır. Örneğin, parașüt ile atlamak üzere olan biri, atlama sırasında paraşütün açılmama ihtimalini düşünerek korku; atlayışı yanlış yapmak suretiyle yanlış yere inmek ve bu sebeple alay konusu olmak düşüncesiyle kaygı yaşar (Özer, 2017).

Diğer bir deyişle, fiziksel ya da yaşamsal bir zarar riski korkuya, başarısız olma, yanlış yapma, alay konusu edilme, utanma, eleştirilme vb. içsel algılar kaygıya sebep olur.

Gerek korkular gerekse kaygılar, yaşamı sürdürebilmek için gerekli olan duygular olmakla beraber aşırı düzeyde yaşanmaları sorunlara yol açabilir.

Yaşamsal tehditlere karşı korku duymak, insanı tehlikelere karşı dikkatli olmaya ve tedbir almaya yönelten ve ölçülü olmak kaydıyla, hayatın devamı açısından son derece önemli bir duygu durumudur. Kaygı da benzer șekilde ölçülü olmak kaydıyla, insana olası riskleri değerlendirme ve önlem alma konusunda faydalı ve yol gösterici olmakla beraber, ölçünün kaçırılması durumunda, kısırdöngülerle oluşacak yüksek kaygı düzeylerinde, aşırı stres yüklenmek, kendimize olan güveni ve inancı kaybetmek ve hatta ümitsizliğe kapılmak gibi olumsuz sonuçlar doğurabilmektedir (Kennerley, 2017).

Korku ve kaygı konusunda yaptığımız temel açıklamalardan sonra, çalışmamızın da ana unsuru olması sebebiyle, kaygı üzerinde daha ayrıntılı durmak istiyoruz.

Kaygı ile ilgili olarak literatürde çeşitli tanımlamalar mevcuttur. Kaygı, "kaynağı belirsiz korku" (Baltaş ve Baltaş, 1998), "gelecek olumsuzluklara karşı hissedilen rahatsızlık duygusu ya da gerginliğin bedensel belirtileri" (Endler ve Kocovski, 2001; Callea vd., 2012) olarak da tanımlanmaktadır. 
Geniş anlamda kaygı, çevresel ve psikolojik uyaranlara karşı insanın doğası gereği gösterdiği duygusal tepki; dar anlamda ise, kaynağı ve başlangıcı bilinçli olmamasına rağmen bilinçli bir şekilde hissedilen ve beraberinde terleme, sararma gibi fiziksel değișimlerin de görüldügü bir duygu durumu olarak tanımlanmaktadır (Kaya ve Varol, 2004).

Dolayısıyla, günlük yaşam içinde olağan ve temel duygu durumlarından biri olan kaygl, tehdit edici bir durum karşısında birey tarafından hissedilen huzursuzluk ve endişe durumu olarak da ifade edilmektedir.

Kaygı, hemen her birey tarafından az ya da çok yaşanan, hoşlanılmayan, rahatsız edici bir his olarak algılanmakta ve bireyler üzerinde olumsuz etkiler yaratan ve bu sebeple ortaya çıkan davranışların ya da performansın dengesini bozarak başarısızlığa yol açabilen bir duygu durumunu ifade etmektedir (Kurtuldu, 2009).

Kaygının literatürde durumluk kaygı ve sürekli kaygı olmak üzere iki ana başlıkta değerlendirildiğini görmekteyiz. Sürekli kaygının (trait anxiety), bireyin kişiliğinden kaynaklandığı ve genel bir kişilik özelliği olarak ortaya çıktığı kabul edilmektedir. Bu durumdaki kişi içinde bulunduğu koşulları sürekli olarak kaygı verici olarak algılamakta ve yorumlamaktadır. Durumluk kaygı (state anxiety) ise kişilerin özel durumları tehdit edici olarak yorumlaması sonucunda oluşmaktadır (Kutlu, 2001).

Dolayısıyla, durumluk kaygı normal bir duygu olarak kabul edilirken, sürekli kaygı ise tedavi gerektiren bir kişilik özelliği olarak değerlendirilmektedir.

Literatürde bir başka ayrımda da kaygının kişilik, durum ve olay kaynaklı olmak üzere üç farklı şekilde ortaya çıktığı kabul edilmektedir. Buna göre, kişilik kaynaklı kaygı, bazı bireylerde kişiliğin değişmez bir parçası olarak görülmekte ve devamlılık arz etmektedir. Durum kaynaklı kaygı, belirli bir durum karşısında, bu duruma karşı eş zamanlı ve özel olarak ortaya çıkan bir duygu durumunu ifade etmektedir. Olay kaynaklı kaygı ise, belirli olaylar karşısında oluşan duygu durumu olarak tanımlanmaktadır (Aydın ve Zengin, 2008).

Dikkat edilecek olursa üçlü ayrımda yer alan durum ve olay kaynaklı kaygıları durumsal kaygılar; kișilik kaynaklı kaygıları da sürekli kaygılar olarak değerlendirdiğimiz ikili ayrıma ulaşılmış oluyoruz. Bu açıdan bakıldığında, durumsal kaygı, çeşitli tehdit ya da stres faktörleri karşısında sinir sisteminin uyarılması neticesinde ortaya çıkan gerginlik, sinirlilik ya da evham gibi geçici duygu durumları olarak tanımlanmaktadır. Sürekli kaygı ise, kişinin kaygıya yatkınlığı șeklinde değerlendirilmekte ve bu kaygının zaman içinde ortaya çıtı̆̆g kabul edilmektedir (Spielberger ve Reheiser, 2009). Öte yandan, durumsal kaygı kişinin herhangi bir olgunun yaşanması sırasında nasıl hissettiğini ifade ederken; sürekli kaygı ise kişinin genel olarak nasıl hissettiğini tanımlamaktadır (Fountoulakis vd., 2006).

Kişilerin, gelecekte kötü şeyler olacak şeklinde algılayıp anlattıkları kaygı, çok hafif tedirginlik ve gerginlik durumundan panik derecesine varan şiddette ortaya çıkabilir. Kaygı duygusunun yoğunluğu arttıkça davranışlar aksar, algılama ve dikkat bozuklukları görülür.

Kaygının pek çok yaşamsal faaliyet üzerinde etkisi olduğu bilinmekte olup kaygı ile öğrenme arasında da bir ilişki bulunduğu kabul edilmektedir. Öğrenme fiziksel ve psikolojik yönleri olan oldukça karmaşık bir süreçtir.

Öğrenme kaygısı ise, öğrenmeyi zorlaştıran veya bütünüyle engelleyen, bireylerin öğrenmeye yönelik olumsuz tutum takınmasını sağlayan ve bireyde huzursuzluk, stres, endişe, korku, kalp çarpması, terleme vb. durumlar yaratan bir kaygı türüdür. Bireylerin öğrenmeleri sırasında yaşadıkları güçsüzlük durumu öğrenme kaygısı olarak tanımlanmaktadır (Yıldırım, 2015). 
Dolayısıyla, öğrenmenin en üst düzeyde, başarıyla gerçekleșebilmesi için kaygının neden olduğu olumsuz etkilerin giderilmesi ya da en azından azaltılması önem taşımaktadır.

Kaygı ile öğrenme arasında kuvvetli bir ilişsi olduğunu ifade etmiştik. Nitekim bu alanda yapılmış çok sayıda çalışma da bulunmaktadır.

Kaygı ile başarı arasındaki ilişkiyi inceleyen çok sayıda araştırmayı tarayan Scovel, 1978 yılında yayımladığı çalışmasıyla kaygıyı kolaylaştırıcı ve engelleyici olmak üzere iki başlıkta incelemek gerektiğini öne sürmüştür. Buna bağlı olarak kolaylaştırıcı kaygının öğreneni, yeni öğrenme ortamlarında mücadele etmeye ve 'yaklaşma davranışına' iten bir unsur olduğunu; engelleyici kaygının ise yeni öğrenme ortamlarındaki bireyi kaçınma davranışına yönelttiğini ifade etmiştir. Öte yandan Scovel (1978) yine aynı çalışmasıyla, kolaylaștırıcı ve engelleyici kaygının normal bir bireyde bir arada bulunduğunu ve öğrenme süreci içinde karşılaştığı her yeni olgu karşısında öğreneni uyarma ya da motive etme işlevi gördügünü de öne sürmektedir.

Daha açık bir ifadeyle, kolaylaştırıcı kaygı, öğreneni yeni öğrenme ortamlarında daha mücadeleci kılarak yaklaşma davranışına yöneltirken; engelleyici kaygı ise yeni öğrenme ortamlarındaki bireyin kaçınma davranışını benimsemesine sebep olmaktadır (Batumlu ve Erden, 2007).

Kaygının öğrenme üzerindeki bu değişen etkisinin nasıl gerçekleștiğine yönelik olarak yapılan araştırmalarda, kaygı düzeyinin göreceli olarak artmasının öğrenme üzerinde pozitif etki yarattığı ancak kaygı seviyesindeki artışın belirli bir eşik değeri aşması halinde ise ilişkinin negatife döndüğü ve o noktadan itibaren kaygıdaki artışın öğrenmeyi ya da performansı olumsuz yönde etkilediği ortaya konulmuştur (Kennerley, 2017). Dolayısıyla, başlangıçta öğrenmeyi motive edici, kolaylaştırıcı olan kaygı, ilerleyen seviyelerde engelleyici kaygıya dönüşmektedir.

0 halde öğrenme işlevinin layıkıyla yerine gelmesi için kaygı seviyesinin kontrol altında tutulabilmesi önem taşımaktadır.

Çalışmamızın konusu Vigil-Colet, Lorenzo-Seva ve Condon (2008) tarafından geliştirilen İstatistik Kaygı Ölçeğinin (SAS) Türkçe formu için geçerlilik ve güvenirlik özelliklerinin incelenmesini gerçekleştirmektir. Çalışmamızın ana konusunu istatistik kaygısı oluşturduğu için öncelikle bu alanda yapılmış çalışmalara kısaca değinmek istiyoruz.

Bilindiği gibi, istatistik okuryazarlığın öneminin zaman içinde artmasına bağlı olarak, istatistik derslerine ön lisans ve lisans programlarında daha çok yer verilmeye başlanmıştır. Benzer şekilde lisansüstü programlarda da gerek ders olarak gerekse hazırlanacak tezlerin uygulamaları açısından istatistik analiz ve yöntemleri bilmek ve kullanmak zorunlu gelmiștir.

İstatistik derslerinin yaygınlığının ve öneminin artması istatistik kaygısına dikkat çekmeyi getirmiştir. Bu alanda yapılan ilk çalışmalarda, istatistik dersinin matematik temeli sebebiyle, yapının matematik kaygısı ile aynı olduğu varsayılmıștır. Schact ve Stewart (1990), Willcox (1936), Wilson (1927), Papousek vd. (2012), Graveter ve Wallnau (2007), Baloğlu (1999) tarafından yapılmış çalıșmalar bu eksende gerçekleștirilmiștir (Chew ve Dillon, 2014).

İstatistik kaygısı ile matematik kaygısının farklılığını ilk savunanlar 1985 yılında gerçekleştirdikleri çalışmalarıyla Cruise, Cash ve Bolton olmuş ve yazarlar 51 ifade ve 6 alt boyuttan oluşan İstatistiksel Kaygı Değerlendirme Ölçeğini (STARS) geliştirmişlerdir. Ancak, Papousek vd. tarafından 2012 yılında gerçekleștirilen bir çalıșma ile STARS ölçeğinin sadece istatistik kaygısını değil aynı zamanda istatistiğe yönelik tutumları da ölçtüğü ortaya konmuştur. Bu sebeple, istatistik kaygısını ölçmek istendiğinde ölçeğin sadece ilk üç alt boyutunun kullanılması önerilmektedir (Papousek vd.,2012). 
Bunun üzerine bu alanda yapılan çalışmalar hız kazanmış ve istatistik kaygısı ile matematik kaygısı arasında anlamlı pozitif yönlü bir ilişki olduğu tespit edilmiş ancak, matematik kaygısı istatistik kaygısına ait varyansın \%50'den azını açıklayabilmiştir. Böylelikle, matematik kaygısı ile istatistik kaygısı arasında bir ilişki bulunsa da matematik ve istatistik ile ilgili olarak iki farklı kaygı türü oluştuğu anlașılmıştır (Baloğlu, 2004).

İstatistik kaygısının, istatistik içerikli bir ders alındığında ya da bir kursa gidildiğinde veya istatistiksel veriyi toplarken, çözümlerken, analiz ederken veya yorumlarken karşılaşılan bir kaygı türü olarak tanımlandığı ve bu kaygıyı ölçmede başlıca iki tür ölçeğin kullanıldığı görülmektedir. Bunlardan biri, matematik kaygısından elde edilen envanteri kullanmakta; diğeri ise istatistik kaygısını ölçmek üzere özel olarak geliştirilmiş istatistik kaygı ölçeğini kullanmaktadır. Ayrıca, bazı araştırmacıların matematiksel kaygı ölçeğini doğrudan istatistik kaygı ölçeği olarak da kullandığı görülmektedir. (Baloğlu, 2002).

Vigil-Colet ve diğerleri (2008) tarafından geliştirilen SAS, daha önce Cruise ve diğerleri (1985) tarafından geliştirilmiş olan STARS maddeleri arasından yapılan seçimle ve sosyal bilimler alanında en az on yıl deneyimi olan istatistik eğitmenlerinin görüşleri alınarak oluşturulmuştur. Başlangıçta 33 maddeden oluşan ölçek, pilot çalışma sonrasında 9 madde elenerek 3 alt boyuttan (sınav kaygısı, yardım isteme kaygısı ve yorumlama kaygısı) oluşan ve her alt boyutta 8 madde olmak üzere toplamda 24 madde içeren bir ölçek haline gelmiştir (Vigil-Colet vd., 2008).

Chiesi ve diğerleri (2011) tarafından gerçekleştirilen çalışmayla Vigil-Colet ve diğerleri (2008) tarafından geliştirilen ve çalıșmamızın da ana konusunu teșkil eden SAS'ın İtalyanca versiyonunun geçerlilik ve güvenilirliği araştırılmış ve ölçeğin orijinal İspanyol versiyonuyla uyumlu olarak üç faktörlü bir yapı sergilediği tespit edilmiştir (Chiesi vd., 2011).

\section{Yöntem}

\section{Araştırma Modeli}

$\mathrm{Bu}$ çalışmada nicel araştırma yöntemlerinden tarama deseni kullanılmıștır. Bu kapsamda kesitsel çalışma yapılmış olup; birincil veri kaynaklarından anket yoluyla veri toplanmıştır.

\section{Katılımcılar}

Çalışmanın evrenini İstanbul'da bulunan bir devlet yükseköğretim kurumunun ekonometri lisans diploma programına kayıtlı olup; istatistik dersi almış ve sınavına girmiş öğrenciler oluşturmaktadır. Söz konusu diploma programında istatistik dersleri ikinci sınıf itibariyle başlamaktadır. Dolayısıyla bu çalıșmanın evrenini ikinci, üçüncü ve dördüncü sınıf öğrencileri, yani 611 kişi oluşturmaktadır. Bu kapsamda çalışma, 20162017 akademik yılı bahar döneminde istatistik II, uygulamalı istatistik II ve veri madenciliği derslerine kayıtlı öğrenciler üzerine gerçekleştirilmiştir. Söz konusu derslerde sınıf ortamında kâğıt ve kalem kullanılan anket tekniği ile veri toplanmıştır. Çalışmaya gönüllülük esasına göre 350 öğrenci katılmıștır. Başka bir deyişle, çalışmanın örneklem büyüklügü 350 öğrencidir. Bu katılımcıların cinsiyet ve yaş değişkenlerine göre frekans dağılımı Tablo 1'de sunulmuștur. 


\begin{tabular}{|c|c|c|c|}
\hline Değișken & Değişken Düzeyleri & Frekans & \% Frekans \\
\hline \multirow{2}{*}{ Cinsiyet } & Kadın & 227 & 64.9 \\
\cline { 2 - 4 } & Erkek & 123 & 35.1 \\
\hline \multirow{3}{*}{ Yaş } & $18-19$ & 40 & 11.43 \\
\cline { 2 - 4 } & $20-21$ & 211 & 60.29 \\
\cline { 2 - 4 } & $22+$ & 99 & 28.28 \\
\hline
\end{tabular}

Tablo 1: Katılımcıların Demografik Özelliklerinin Frekans Dağılımı

Tablo 1 incelendiğinde; çalıșmanın örnekleminin 227'si kadın (\%64.9) ve 123'ü erkek (\%35.1) olmak üzere toplam 350 öğrenciden meydana geldiği görülmektedir. Bu öğrencilerin \%88.57'sinin yaşı 20 yaş ve üzeridir.

\section{Veri Toplama Araçları}

Çalışmada veri toplama aracı olarak kişisel bilgi formu ve istatistik kaygı ölçeği kullanılmıștır.

\section{Kişisel Bilgi Formu}

Katılımcıların demografik özelliklerini ortaya koymak amacıyla yöneltilen yaş ve cinsiyet sorularının yanı sıra devam edilmekte olan sınıf ve ilgili istatistik dersindeki başarı notu sorulmuştur.

\section{İstatistik Kaygı Ölçeği (Statistical Anxiety Scale - SAS)}

Vigil-Colet ve diğerleri (2008) tarafından geliştirilmiş olup; 24 madde ve üç alt boyuttan meydana gelmektedir. Bu boyutlar; yorumlama kaygısı, sınav kaygısı ve yardım isteme kaygısı olarak adlandırılmıştır. Her bir boyutta 8 madde bulunmaktadır. Katılımcılar, bu maddelere "1- hiç kaygı taşımama" ile "5- yüksek düzeyde kaygılı olma" durumu arasında beş dereceli bir skalada hissettikleri kaygı düzeylerini belirtmektedir. Ölçekte yer alan tüm maddeler olumlu ifadelerden oluşmakta ve yüksek puanlar yüksek kaygı seviyelerini göstermektedir.

Vigil-Colet ve diğerleri (2008) tarafından yapılan çalışma kapsamında geçerlilik ve güvenilirlik analizi gerçekleştirilmiştir. Bu bağlamda içsel tutarlılık güvenilirliği için Cronbach alfa katsayısı hesaplanmıştır. Cronbach alfa katsayısı; ölçek için 0.91, yorumlama kaygısı için 0.82, sınav kaygısı için 0.87 ve yardım isteme kaygısı 0.92 olarak bulunmuştur. Bunun yanı sıra geçerlilik için sürekli kaygı ve nevrotizm yapılarını ölçen araçlarla toplanmıș verilerden hareketle hesaplanan korelasyon katsayısına dayanan eş zamanlı geçerliliği incelenmiştir. Elde edilen bulgular, Vigil-Colet ve diğerleri (2008) tarafından geliştirilmiş ölçeğin geçerlilik özelliğine sahip olduğunu göstermiştir.

Bu çalışmada Vigil-Colet ve diğerleri (2008) tarafından istatistik kaygısını ölçmek amacıyla geliştirilmiş olan ölçeğin Türkçeye tercümesi ve adaptasyonu gerçekleştirilmiştir. Bu aşamada, geri çeviri yöntemi kullanılmıştır. Orijinal ölçek ve geri çeviri ile elde edilen form arasındaki benzerlikler ve farklılık incelenmiştir. Takip eden aşamada geri çeviri versiyonu için dil uygunluğunun ve kavramsal anlamlılığının incelenmesi amacıyla uzman görüşüne başvurulmuştur. Son aşamada ise, çalışmanın evreninde yer alan 50 öğrenciden oluşan bir toplulukla pilot uygulama gerçekleștirilmiştir. Böylelikle söz konusu ölçme aracının dil ve kültür uyarlaması yapılmıștır. 


\section{İşlem}

Çalışmanın amacı doğrultusunda daha önceden istatistik sınavına girmiş öğrenciler, sınıf ortamında gönüllülük esasına dayalı olarak soru formunu yanıtlamaya davet edilmiștir. Bu așamada öncelikle çalıșmanın amacından bahsedilmiş ve soru formu kısaca tanıtılmıştır. Kâğıt ve kalem kullanılan anket tekniği ile veri toplanmış olup; katılımcıların soru formunu cevaplandırması ortalama 4 dakika sürmüştür.

\section{Veri Analizi}

Bu çalışmada Vigil-Colet ve diğerleri (2008) tarafından geliştirilmiş olan SAS'ın Türkçe versiyonunun psikometrik özelliklerinin incelenmesi amaçlanmıştır. Bu bağlamda verinin söylediğini yani doğasını ortaya çıkarması hedefiyle açıklayıcı faktör analizi (AFA) uygulanmıștır. AFA, gözlenen değișkenler arasındaki doğrusal ilișkilerden hareketle; veri kümesinin ardında yatan gizil yapıları keșfetmeyi amaçlamaktadır. Dolayısıyla bu çalışmada öncelikle AFA uygulanmış, ardından türetilen faktörler için içsel tutarlılık güvenilirliği hesaplanmıștır. Son olarak ise, faktörler arası korelasyon matrisi oluşturulmuştur.

Çalıșmada Urbano Lorenzo-Seva ve Pere Joan Ferrando tarafından geliştirilmiş olan FACTOR programı ve SPSS kullanılarak veri analizi gerçekleştirilmiştir.

\section{Bulgular}

SAS ile toplanan veri kümesinde her bir madde için geçerli ve kayıp gözlemler incelenmiştir. $\mathrm{Bu}$ aşamada yardım isteme kaygısını ölçmek amacıyla yöneltilen "Hiç anlamadığım bir konuyu açıklaması için ücret karşılığında bir istatistik uzmanına sorduğumda" ve "Bir sorunun nasıl yapılacağını anlatması için ücret karşılığı bir istatistik uzmanından yardım isterken" maddeleri için kayıp gözlem sayısının yüksek olduğu saptanmıştır. Katılımcıların neredeyse tamamı, bu maddeler için "fikrim yok" yanıtını vermiştir. Ücret karşılığında destek almayı deneyimlemedikleri için bu seçeneği işaretledikleri düşünüldüğünden; bu iki madde analiz dışında bırakılmıștır.

SAS ile toplanan veri kümesinin doğasını yansıtmak amacıyla AFA uygulanmasına karar verilmiştir. Böylelikle ölçeğin orijinal yapısı ile bu çalışmada toplanan veri kümesinin ardındaki yapının aynı olup olmadığı kıyaslanmıştır. Öncelikle gözlenen değişkenler arasındaki korelasyon matrisinin faktör analizine uygunluğu araştırılmıştır. Bu kapsamda Bartlett küresellik testinin sonucu ve Kaiser-Meyer-Olkin (KMO) örneklem yeterlilik ölçütünün değeri dikkate alınmıştır. Bartlett küresellik testi $\left(\chi^{2}=5120.9, d f=\right.$ $231, p=0,00)$ ve KMO ölçütünün değeri (0.948) korelasyon matrisinin AFA uygulanması için elverişli olduğunu göstermiştir. Ardından minimum sıra faktör analizi (minimum rank factor analysis - MRFA) metodu ile faktör modeli tahmin edilmiştir (ten Berge ve Kiers, 1991). Uygun faktör sayısına karar verilmesinde Kaiser-Guttman kuralı, Hull yöntemi, varyans yüzdesi kriteri, yorumlanabilirlik kriteri dikkate alınmış ve böylelikle faktör sayısı 3 olarak belirlenmiştir. Dolayısıyla veri kümesinin ardında üç faktör olduğu, yani ölçeğin üç boyuttan oluştuğu sonucuna varılmıştır. Faktör yükleri incelendiğinde basit faktör yapısına ulaşmak için eğik döndürme metotlarından biri olan Promin kullanılmıştır (Lorenzo-Seva,1999). Tablo 2'de maddelere ait tanımlayıcı istatistikler, faktör yükleri, açıklanan varyans oranı ve madde sayısı yer almaktadır. 


\begin{tabular}{|l|l|l|l|l|l|}
\hline Faktör / Maddeler & Ortalama & $\begin{array}{l}\text { Standart } \\
\text { Sapma }\end{array}$ & $\begin{array}{l}\text { Faktör } \\
\text { Yükü }\end{array}$ & $\begin{array}{l}\text { Açlklanan } \\
\text { Varyans (\%) }\end{array}$ & $\begin{array}{l}\text { Madde } \\
\text { Sayısı }\end{array}$ \\
\hline Sınav KaygıSı (S) & & & & 28.6 & 8 \\
\hline $15 \mathrm{~S}$ & 3.631 & 1.288 & 0.918 & & \\
\hline $20 \mathrm{~S}$ & 3.540 & 1.399 & 0.828 & & \\
\hline $9 \mathrm{~S}$ & 3.242 & 1.499 & 0.806 & & \\
\hline $13 \mathrm{~S}$ & 3.311 & 1.427 & 0.778 & & \\
\hline $14 \mathrm{~S}$ & 2.900 & 1.458 & 0.739 & & \\
\hline $1 \mathrm{~S}$ & 3.074 & 1.446 & 0.644 & & \\
\hline $4 \mathrm{~S}$ & 3.480 & 1.349 & 0.640 & & \\
\hline $11 \mathrm{~S}$ & 2.731 & 1.423 & 0.594 & & \\
\hline $\begin{array}{l}\text { Yardım İsteme KaygıSI } \\
\text { (Yi) }\end{array}$ & & & & 27.7 & \\
\hline $17 \mathrm{YI}$ & 2.300 & 1.345 & 0.922 & & \\
\hline $21 \mathrm{YI}$ & 2.420 & 1.397 & 0.877 & & \\
\hline $23 \mathrm{YI}$ & 2.443 & 1.412 & 0.877 & & \\
\hline $3 \mathrm{YI}$ & 2.583 & 1.496 & 0.819 & & \\
\hline $12 \mathrm{YI}$ & 2.440 & 1.424 & 0.776 & & \\
\hline $7 \mathrm{YI}$ & 2.363 & 1.417 & 0.759 & & \\
\hline Yorumlama KaygıSI (Y) & & & & 23.8 & \\
\hline $22 \mathrm{Y}$ & 2.629 & 1.291 & 0.907 & & \\
\hline $18 \mathrm{Y}$ & 2.240 & 1.287 & 0.906 & & \\
\hline $10 \mathrm{Y}$ & 2.523 & 1.304 & 0.743 & & \\
\hline $8 \mathrm{Y}$ & 2.600 & 1.350 & 0.659 & & \\
\hline $19 \mathrm{Y}$ & 2.223 & 1.320 & 0.597 & & \\
\hline $6 \mathrm{Y}$ & 2.537 & 1.297 & 0.591 & & \\
\hline $16 \mathrm{Y}$ & 2.357 & 1.348 & 0.500 & & \\
\hline $2 \mathrm{Y}$ & 2.629 & 1.275 & 0.468 & & \\
\hline
\end{tabular}

Tablo 2: Açıklayıcı Faktör Analizi Sonuçları

Tablo 2 incelendiğinde AFA ile türetilen üç faktör ve bu faktörler altında yer alan maddeler görülmektedir. Böylelikle veri kümesi özetlenmiş ve boyut indirgemesi gerçekleștirilmiştir. Diğer bir ifadeyle, gözlenen değişken sayısından daha az sayıda ve kavramsal olarak anlamlı faktörler türetilmiștir. Vigil-Colet ve diğerleri (2008) tarafından gerçekleştirilen çalışmaya uygun olarak faktörler; sınav kaygısı (S), yardım isteme kaygıSı (Yİ) ve yorumlama kaygısı (Y) şeklinde adlandırılmıștır. Her bir faktör altındaki maddeler ise $\mathrm{S}$, Yİ ve Y ile sembolize edilmiştir. Faktör yükleri incelendiğinde; en düșük yükün 0.468 olduğu görülmektedir. Bunun yanı sıra toplam açıklanan varyans \%80.1'dir. Kısıtsız faktör analizi, yani AFA ile verinin söylediği yapı ortaya çıkarılmış ve bulunan faktör yapısının orijinal faktör yapısı ile örtüştüğü sonucuna varılmıştır. Dolayısıyla ölçülmek istenen alt boyutlar isabetli olarak ölçülmüştür. Başka bir deyişle, ölçülmek istenilenin yapılar isabetli olarak ölçüldügünden geçerlilik özelliğinin sağlandığı söylenebilmektedir. Takip eden aşamada ise SAS'ın Türkçe formu ile toplanan veri kümesinin güvenilirlik özelliği araştırılmıştır. Bu kapsamda, sosyal bilimler alanında yaygın olarak kullanılan Cronbach alfa katsayısı hesaplanmıştır. Tablo 3'te içsel tutarlılık güvenilirliği için hesaplanan Cronbach alfa katsayısı değerleri sunulmuştur. 


\begin{tabular}{|l|l|l|l|l|}
\hline \multirow{2}{*}{ Faktör } & \multirow{2}{*}{$\begin{array}{l}\text { Madde } \\
\text { Sayısı }\end{array}$} & \multirow{2}{*}{$\begin{array}{l}\text { Cronbach } \\
\text { Alfa }\end{array}$} & $\begin{array}{l}\text { Madde-Toplam Korelasyon } \\
\text { Değeri }\end{array}$ \\
\cline { 4 - 5 } & 8 & 0.912 & En Düşük & En Yüksek \\
\hline Sınav Kaygısı & 8 & 0.633 & 0.787 \\
\hline $\begin{array}{l}\text { Yardım İsteme } \\
\text { KaygıSı }\end{array}$ & 6 & 0.747 & 0.835 \\
\hline $\begin{array}{l}\text { Yorumlama } \\
\text { Kaygısı }\end{array}$ & 8 & 0.884 & 0.618 & 0.705 \\
\hline
\end{tabular}

Tablo 3: Güvenilirlik Analizi

Tablo 3 incelendiğinde; içsel tutarlılık güvenilirliği için hesaplanan Cronbach alfa katsayısının değerlerinin 0.70 ve üzeri olduğu görülmektedir. Bu bulgu, toplanan veri kümesinin güvenilirlik özelliğine sahip olduğunu göstermektedir (Nunnally ve Bernstein, 1994). Bunun yanı sıra madde-toplam korelasyon değeri de sunulmuştur.

Bu çalışmada AFA ile kavramsal olarak anlamlı ve yorumlanabilir faktörler türetilmiştir. Dolayısıyla bu faktörler arası korelasyon matrisinin incelenmesi, boyutlar arasındaki ilişkiyi kavramak açısından önem arz etmektedir. Bu bağlamda yanıtların toplanması yaklaşımı ile faktör skorları hesaplanmış ve Tablo 4'te değişkenler arası korelasyon matrisi sunulmuștur.

\begin{tabular}{|l|l|l|l|}
\hline & $\begin{array}{l}\text { Sınav } \\
\text { Kaygısı }\end{array}$ & $\begin{array}{l}\text { Yardım İsteme } \\
\text { Kaygısı }\end{array}$ & $\begin{array}{l}\text { Yorumlama } \\
\text { Kaygısı }\end{array}$ \\
\hline Sınav Kaygısı & 1.000 & & \\
\hline $\begin{array}{l}\text { Yardım İsteme } \\
\text { Kaygısı }\end{array}$ & $0.581^{*}$ & 1.000 & \\
\hline Yorumlama KaygıSı & $0.675^{*}$ & $0.684^{*}$ & 1.000 \\
\hline
\end{tabular}

*0.01 düzeyinde istatistiksel olarak anlamlıdır.

Tablo 4: Sınav Kaygısı, Yardım İsteme Kaygısı ve Yorumlama Kaygısı Değişkenleri Arasındaki Korelasyon Matrisi

Tablo 4 incelendiğinde; değișkenler arasında aynı yönlü ve orta kuvvetli bir ilişki olduğu görülmektedir. Hatırlanacağı üzere; SAS, üç alt boyuttan meydana gelmektedir. Dolayısıyla alt boyutlar arasında aynı yönlü ve orta kuvvetli bir ilişki olması beklenen bir durumdur.

\begin{tabular}{|l|l|l|l|}
\hline Değişken & Madde Sayısı & Ortalama & Standart Sapma \\
& & & \\
\hline Sınav KaygıSı & 8 & 25.911 & 8.894 \\
\hline Yardım İsteme Kaygısı & 6 & 14.549 & 7.255 \\
\hline Yorumlama KaygıSı & 8 & 19.737 & 7.778 \\
\hline SAS & 22 & 60.197 & 20.92 \\
\hline
\end{tabular}

Tablo 5: Değişkenlere Ait Tanımlayıcı İstatistikler 
Tablo 5 incelendiğinde her bir değişken için ortalama ve standart sapma değerleri görülmektedir. Hatırlanacağı üzere; katılımcılar kaygı düzeylerini 1 ile 5 arasında beş dereceli bir ölçekte belirtmiş ve bütün maddeler olumlu ifadelerden oluşmuștur. Dolayısıyla yüksek skor, yüksek kaygı düzeyini göstermektedir. Bu bağlamda en yüksek kaygının hissedildiği faktörün sınav kaygısı olduğu sonucuna varılmıștır.

\section{Tartışma ve Sonuç}

Bu çalışmada Vigil-Colet ve diğerleri (2008) tarafından geliştirilmiş olan istatistik kaygı ölçeğinin Türkçe versiyonunun psikometrik özelliklerinin incelenmesi amaçlanmıştır. Yani, istatistik dersi alırken karşılaşılan kaygıyı değerlendirmek için geliştirilen SAS'ın geçerlilik ve güvenilirlik özellikleri incelenmiştir. SAS, 24 madde ve üç alt boyuttan meydana gelmektedir. Bu kapsamda öncelikle geri çeviri yöntemi ile SAS'ın dil ve kültür uyarlaması yapılmıştır. Ardından İstanbul'da bulunan bir devlet yüksekögretim kurumunun ekonometri lisans diploma programına kayıtlı olup; istatistik dersi almış ve sınavına girmiş öğrencilerden kâğıt ve kalem kullanılan anket tekniği ile sınıf ortamında veri toplanmıștır. Çalıșmaya gönüllülük esasına göre 350 öğrenci katılmıștır. Toplanan veri kümesinden hareketle; verinin doğasını yansıtması amacıyla kısıt faktör analizi uygulanmıştır. Böylelikle veri kümesinin ardındaki gizil yapı keşfedilmiş; bulunan faktör yapısının Vigil-Colet ve diğerleri (2008) tarafından ortaya konulan faktör yapısı ile örtüştüğü sonucuna varılmıștır. Dolayısıyla söz konusu ölçek için geçerlilik özelliğinin sağlandığı söylenebilmektedir. Bunun yanı sıra içsel tutarlılık güvenilirliği için Cronbach alfa katsayısı hesaplanmış ve elde edilen bulgular neticesinde güvenilirlik özelliğinin de sağlandığını tespit edilmiştir. Böylelikle SAS ile toplanan veri kümesinin geçerli ve güvenilir olduğu ortaya konulmuştur. Ardından faktör skorları hesaplanmış olup; bu çalışma kapsamında en yüksek kaygı hissedilen faktörün sınav kaygısı olduğu saptanmıştır.

Çalışmada ulaşılan bulgular, Türkçeye uyarlanan SAS'ın geçerli ve güvenilir olduğunu göstermiștir. Başka bir ifadeyle, SAS ile toplanan veri kümesinin istenilen psikometrik özelliklere sahip olduğu ortaya konulmuştur. SAS'ın sadece istatistik kaygısını ölçmeye odaklanmış olmasının yanı sıra bireysel ya da sınıf gruplarında kolayca uygulanabilmesi önemli bir avantaj olarak görülmektedir. Dolayısıyla bu alanda yapılacak çalışmalarda SAS'ın Türkçe versiyonunun kullanılması önerilmektedir. Bu ölçek kullanılarak öğrencilerin istatistik kaygısı ölçülebilecek, böylelikle istatistik kaygısı ve onu etkileyen faktörler arasındaki ilişkiler incelenerek öğrencilerdeki istatistik kaygı düzeyi düşürülebilecektir.

Çalışmanın kısıtları olarak, örneklemin sadece devlet yükseköğretim kurumunun ekonometri lisans programına kayıtlı öğrencilerinden oluşması ve örneklem büyüklüğünün 350 kişi ile sınırlı kalması gösterilebilmektedir. Gelecek araștırmalarda daha geniş ve çeşitlilik gösteren bir örneklemle çalışılmasının faydalı olacağı düşünülmektedir. Bunun yanı sıra farklı ülkelerde SAS ile veri toplanarak; ülkeler arası karşılaştırılmaların yapılması da önerilmektedir. Ayrıca gelecek çalışmalarda istatistik kaygısını etkileyen faktörlerin araştırılması ve bu faktörler arasındaki nedensel ilişkilerin modellenmesi de faydalı olacaktır.

\section{KAYNAKÇA}

AYDIN, S. ve ZENGIN, B. (2008). Yabancı Dil Öğreniminde Kaygı: Bir Literatür Özeti. Journal of Language and Linguistic Studies, 2008, 4(1), 81-94. 
BALOĞLU, M. (2002). Psychometric Properties of the Statistics Anxiety Rating Scale. Psychological Reports, 90,315-325. https://doi.org/10.2466/pr0.2002.90.1.315

BALOĞLU, M. (2004). Statistics Anxiety and Mathematics Anxiety: Some Interesting Differences I. Educational Research Quarterly, 27(3), 38-48.

BALTAȘ, A. ve BALTAȘ, Z. (1998). Stres ve Başa Çıkma Yolları (18. Baskı). İstanbul: Remzi Kitabevi.

BATUMLU, D. Z. ve ERDEN, M. (2007). Yıldız Teknik Üniversitesi Yabancı Diller Yüksek Okulu Hazırılı Öğrencilerinin Yabancı Dil Kaygıları ile İngilizce Başarıları Arasındaki İlişki. Eğitimde Kuram ve Uygulama, 3(1), 24-38.

CALLEA, A., URBINI, F., ve BUCKNOR, D. (2012). Temporary Employment in Italy and its Consequences on Gender. Gender in Management: An International Journal, 27(6), 380-394. https://doi.org/10.1108/17542411211269329

CHIESI, F., PRIMI, C. ve CARMONA, J. (2011). Measuring Statistics Anxiety: CrossCountry Validity of the Statistical Anxiety Scale (SAS). Journal of Psychoeducational Assessment, 29(6), 559-569. https://doi.org/10.1177/0734282911404985

CHEW, P. K. H ve DILLON, D. B. (2014). Statistics Anxiety Update: Refining the Construct and Recommendations for a New Research Agenda. Perspectives on Psychological Science, 9(2), 196-208. https://doi.org/10.1177/1745691613518077

CRUISE, R.J., CASH, R.W. ve BOLTON, D.L. (1985). Development and validation of an instrument to measure statistical anxiety. Proceedings of the American Statistical Association, 92-97.

ENDLER, N. S. ve KOCOVSKI, N. L. (2001), State and Trait Anxiety Revisited. Journal of Anxiety Disorders, 15(3), 231-245. https://doi.org/10.1016/S08876185(01)00060-3

FOUNTOULAKIS, K. N., PAPADOPOULOU, M., KLEANTHOUS, S., PAPADOPOULOU, A., BIZELI, V., NIMATOUDIS, I., IACOVIDES, A. ve KAPRINIS, G. S. (2006). Reliability and Psychometric Properties of the Greek Translation of the State-Trait Anxiety Inventory Form Y: Preliminary Data. Annals of General Psychiatry, 5(2), 1-10.

https://doi.org/10.1186/1744-859X-5-2

KAYA, M. ve VAROL, K. (2004). İlahiyat Fakültesi Öğrencilerinin Durumluk-

Sürekli Kaygı Düzeyleri ve Kaygı Nedenleri (Samsun Örneği). Ondokuz Mayıs Üniversitesi Illahiyat Fakültesi Dergisi, 17(17), 31-63.

KENNERLEY, H. (2017). Kaygı (Anksiyete) (2. Baskı). (Nur Yener, Çev.) İstanbul: Kuraldışı Yayınevi.

KURTULDU, M. K. (2009). Müzik Öğretmenliği Bölümü Piyano Öğrencilerinin Sınav Kaygısına Yönelik Tutumları. Fırat Üniversitesi Sosyal Bilimler Dergisi, 19(2),107126.

KUTLU, Ö. (2001). Ergenlerin Üniversite Sınavlarına İlişkin Kaygıları. Eğitim ve Bilim, 26(121),12-23.

LORENZO-SEVA, U. (1999). Promin: A method for oblique factor rotation.

Multivariate Behavioral Research, 34, 347-365.

https://doi.org/10.1207/S15327906MBR3403_3

NUNNALLY, J. C. ve BERNSTEIN, I. H. (1994). Psychometric theory (Third Edition). New York: MacGraw-Hill.

ÖZER, A. K. (2017). Kaygı - Sinanma Duygusuyla Baş Edebilme (8.basım). İstanbul: Aura Kitapları.

PAPOUSEK, I., RUGGERI, K., MACHER, D., PAECHTER, M., HEENE, M., WEISS, E. M., SCHULTER, G. ve FREUDENTHALER, H. H. (2012). Psychometric Evaluation and Experimental Validation of the Statistics Anxiety Rating Scale, Journal of Personality Assessment, 94(1),82-91. https://doi.org/10.1080/00223891.2011.627959 
SCOVEL, T. (1978). The Effect of Affect on Foreign Language Learning: A Review of the Anxiety Research. Language Learning, 28(1),129-142.

https://doi.org/10.1111/j.1467-1770.1978.tb00309.x

SPIELBERGER, C. D. ve REHEISER, E. C. (2009). Assessment of Emotions: Anxiety, Anger, Depression and Curiosity. Applied Psychology: Health and Well-Being, 1(3), 271302. https://doi.org/10.1111/j.1758-0854.2009.01017.x

TEN BERGE, J.M.F. ve KIERS, H.A.L. (1991). A numerical approach to the approximate and the exact minimum rank of a covariance matrix. Psychometrika, 56(2), 309-315.

VIGIL-COLET, A., LORENZO-SEVA, U. ve CONDON, L. (2008). Development and validation of the statistical anxiety scale. Psicothema, 20(1),174-180.

YAMAN, H. (2010). Writing Anxiety of Turkish Students: Scale Development and the Working Procedures in Terms of Various Variables. International Online Journal of Educational Sciences, 2 (1), 267-289.

YILDIRIM, B. (2015). Fen Bilimleri Öğrenme Kaygı Ölçeği: Geçerlilik ve Güvenirlik Çalışması. Muş Alparslan Üniversitesi Sosyal Bilimler Dergisi, 3(1), 33-43.

\section{Summary}

Nowadays, there is a general perception that students take a negative attitude towards statistics courses which increases statistical anxiety. Statistical anxiety is defined as "feelings of anxiety encountered when taking a statistics course or doing statistical analyses, that is, gathering, processing, and interpret[ing data]" (Cruise, Cash and Bolton, 1985). Due to the increase in the number of statistics courses and its importance, the number of studies on statistical anxiety level has also increased. Thus, there are many statistical anxiety scales developed in the literature. In this paper, a statistical anxiety scale (SAS) developed by VigilColet, A., Lorenzo-Seva, U. and Condon, L., (2008) was adopted due to its sole focus on measurement of statistical anxiety as well as its easy applicability to individual and classroom groups. The validity and reliability properties of the Turkish version of this scale are investigated in this study.

SAS is a scale with a set of 24 items and consists of three dimensions; interpretation anxiety, examination anxiety and asking for help anxiety. All items on this scale are positive expressions and high scores indicate high anxiety levels. As a first step, the SAS was adapted to the language and culture. In this stage, the Turkish survey was developed by using the back-translation method followed by expert opinion consultation and pilot implementation. After several feedback cycles, the Turkish version of SAS was finalized. In the second step, the survey used to collect data from the students who enrolled in the statistics course and took the exam. The population of the study was defined as students enrolled in an econometrics undergraduate program at a state university. Data was collected from 350 students voluntarily in the classroom environment. First, descriptive statistics were calculated for the questions given in the personal information form. Thus, the gender and age characteristics of the study were described. Then, the frequency distributions of the items were examined. The number of missing observations was found to be high for the following items. "Asking a private teacher to explain a topic that I have not understood at all" and "Asking a private teacher to tell me how to do an exercise". Therefore, these two items were excluded from the analysis and other statistical analyses were performed on the remaining 22 items. In the study, exploratory factor analysis (EFA), reliability and correlation analyses were applied respectively. Since the language and culture were adapted for SAS within the scope of the study; exploratory factor analysis was carried out to discover the nature of the data, in other words, to reveal the hidden structures behind the data. The findings revealed three factors; 
"examination anxiety", "asking for help anxiety" and "interpretation anxiety". Therefore, it was concluded that the factor structure found in this study was consistent with the original factor structure of the scale. This showed that the data set collected by the Turkish version of SAS is valid. In the last stage, correlations between variables are calculated after the factors scores for examination anxiety, asking for help anxiety, and interpretation anxiety are calculated. In line with the literature, there are positive and moderate correlations between the variables. The other finding of this study is that examination anxiety is the biggest factor among others. Therefore, by analyzing the relationships between statistical anxiety and determinant factors, SAS is a useful scale for measuring the statistical anxiety to develop recommendations for managing the statistical anxiety level of students. The findings of this study show that the Turkish version of the SAS is valid and reliable. In other words, the dataset collected by the scale has desired psychometric properties. Therefore, we suggest using the Turkish version of SAS in studies conducted in this field.

Ek: İstatistik Kaygı Ölçeği (SAS)

\begin{tabular}{ll}
\hline $\begin{array}{l}\text { Madde } \\
\text { No }\end{array}$ & Madde \\
\hline 1 & İstatistik dersinin sınavına çalışırken \\
\hline 2 & Bir ders kitabındaki/ders notundaki tablonun anlamını yorumlarken \\
\hline 3 & $\begin{array}{l}\text { Anlamakta zorlandığım bir ders kitabı/ders notu için istatistik } \\
\text { hocasından bireysel yardım isterken }\end{array}$ \\
\hline 4 & $\begin{array}{l}\text { Sınavdan bir gün önce kolay sandığım problemleri çözemediğimi fark } \\
\text { ettiğim zaman }\end{array}$ \\
\hline 5 & $\begin{array}{l}\text { Hiç anlamadığım bir konuyu açıklaması için ücret karşılığında bir } \\
\text { istatistik uzmanına sorduğumda }\end{array}$ \\
\hline 6 & İstatistiksel analizler içeren bir ders kitabı/ders notu okuduğumda \\
\hline 7 & $\begin{array}{l}\text { Dersin hocasına bir olasılık tablosunun (z, t, ki-kare vb.) nasıl } \\
\text { kullanılacağını sorduğumda }\end{array}$ \\
\hline 9 & Bir matematiksel formülü/ispatı anlamaya çalışırken \\
\hline 10 & $\begin{array}{l}\text { İstatistik dersinin final sınavındayken } \\
\text { arası homobil reklamını incelerken ortalama yakıt tüketimi, 0-100 km } \\
\text { ilişkin şekilleri/sayıları anlamaya çalışırken }\end{array}$ \\
\hline 11 & İstatistik sınavına gireceğim sınıfa doğru yürürken/yaklaştıkça \\
\hline 12 & $\begin{array}{l}\text { İstatistik dersiyle ilgili bir alıştırmanın/ödevin nasıl yapılacağı } \\
\text { hakkında dersin hocasına soru sorarken }\end{array}$ \\
\hline 13 & $\begin{array}{l}\text { İstatistik sınavından bir gün önce işlediğimiz tüm konuları gözden } \\
\text { geçiremediğimde }\end{array}$ \\
\hline 14 & İstatistik sınavına gireceğim gün sabah uyandığımda \\
\hline 15 & $\begin{array}{l}\text { Sınava girmeden hemen önce bir konuyu yeterince anlamadığımı fark } \\
\text { ettiğimde }\end{array}$ \\
\hline 16 & $\begin{array}{l}\text { İstatistik hocamın tahtaya yazdığı matematiksel bir formülü/ispatı tam } \\
\text { ve doğru şekilde defterime geçirmeye çalışırken }\end{array}$ \\
\hline 17 & $\begin{array}{l}\text { Bir istatistik paket program (SPSS vb.) çıktısını anlamak için istatistik } \\
\text { hocamdan yardım isterken } \\
\text { Şans oyunlarında (piyango, sayısal loto vb.) kazanma olasılıklarını } \\
\text { anlamaya çalışırken }\end{array}$ \\
\hline &
\end{tabular}


19 Sınıf arkadaşımın kendi çözdüğü istatistik probleminin sonuçlarını pür dikkat incelerken gördüğümde

\begin{tabular}{ll}
\hline 20 & Çalışmaya yeterince vakit ayıramadan istatistik sınavına girerken \\
\hline 21 & $\begin{array}{l}\text { Bir sonuç tablosunu yorumlamak için istatistik hocamdan yardım } \\
\text { isterken }\end{array}$ \\
\hline 22 & $\begin{array}{l}\text { Bir gazetede/TÜİK web sitesinde/ Merkez Bankası raporunda yer alan } \\
\text { istatistiksel analizleri anlamaya/yorumlamaya çalışırken }\end{array}$ \\
\hline 23 & Soru sormak için istatistik hocamın odasına giderken \\
\hline 24 & $\begin{array}{l}\text { Bir sorunun/ödevin nasıl yapılacağını anlatması için ücret karşılığı bir } \\
\text { istatistik uzmanından yardım isterken }\end{array}$ \\
\hline
\end{tabular}

